\title{
History Textbook Development Based on Historical Thinking
}

\author{
Zafri $^{1 *}$, Hera Hastuti ${ }^{2}$, Zul 'Asri ${ }^{3}$, and Iqrima Basri ${ }^{4}$ \\ ${ }^{1234}$ History Department, Faculty of Social Science, Universitas Negeri Padang, Padang, Indonesia \\ "Corresponding author. Email: zafrisejarahunp@gmail.com
}

\begin{abstract}
The need for textbooks in learning is the most urgent thing, including in history learning. However, until now there have been no textbooks that are a learning resource for students which are arranged based on historical characteristics itself, namely historical thinking. So far, historical thinking has only been discussed as part of historical science. In fact, Thinking History is the main purpose why history should be taught to students. Studying history, students understand chronology, have the ability to analyze the causes and effects, causes and effects of an event, are able to interpret, think about three dimensions of time, and are able to take the values of these events that can be applied. In this life, these are all stages of Historical Thinking. Therefore, this study aims to produce textbooks designed in accordance with historical thinking. The material does not focus on describing facts, but rather analyzes facts and invites readers, especially students, to be trained in historical thinking. The research method used is Research and Development, with the ADDIE model. However, this research is limited to the development process only. So that a textbook is produced, namely the Textbook of the History of Islamic Civilization in Indonesia.
\end{abstract}

Keywords: Historical Thinking, Historical Learning, Textbooks

\section{INTRODUCTION}

James A. Banks, states that the critical power and intelligence of students in understanding past events makes them wise because they take lessons from people's experiences in the past for the future. All the abilities that these students must have can of course be obtained with the guidance of teachers who understand how history should be taught [1]. Analysis of historical events that took place in the past requires a sharpness of interpretation that goes beyond the ability to "search for information in the text." The sharpness of student interpretation can only be obtained if they have the ability to think history. Wineburg states that historical thinking is Charting the future of teaching the past. In essence, the past can be meaningful if used for the present and future life [2]. The ability to think history includes the ability to interpret historical events, the ability to causality, the ability to interpret or capture the moral dimension of each event, and the three-dimensional ability of time, namely analyzing the past, for present life and interpreting the future [2] [3].

In practice there are many irregularities in history learning, which focuses more on the amount of material that must be conveyed to students. This has an impact on the ability of students who are only at the level of changing words, not analyzing, interpreting and reviewing texts. The presentation of the text for them is closely related to its content; they read for information. Most students think that if they understand all the words and can change the composition of the text they have successfully read the text [2]. Not only students, teachers also believe in this. In addition, reviews of historical learning materials are generally still focused on describing basic facts about an event. Although not entirely like that, when compared to the monotonous learning of creative history, there is still less sharpening in analyzing events [4]. So it is not surprising that the product of learning history is memorization, not understanding, let alone being able to apply historical thinking.

In essence, the various problems above originate from history books, Johanson's findings conclude that the concept of historical thought is not made explicitly in history books. This means that the textbooks circulating so far have not been able to communicate historical thoughts in reviewing historical events [5]. The application of historical thinking in new historical textbooks is at the level of chronology and causality, while inviting children to interpret events, think in three dimensions of time and take the meaning or value of historical events, arguably minimal 
or even nonexistent. Abdullah, et al., stated that in Malaysia recently textbooks have been made which are not only a reflection of factual knowledge but have applied meaningful skills to their students known as Historical Thinking Skills [6].

Based on the problems found, this study aims to develop a history textbook based on an analysis of historical thinking. Writing textbooks whose material descriptions are based on historical thinking is an urgent matter to do. Not only teaching history correctly to students but also inviting teachers to prioritize historical thinking in the learning process, both in reviewing material in front of the class, and when supervising student discussions.

\section{RESEARCH METHODOLOGY}

The research method is Research and Development (R\&D). Needs analysis is the basic foundation in its development, resulting in a history textbook based on historical thinking [7]. The development model used is the ADDIE model, because it is effective, dynamic and supports the performance of the program itself [8]. The ADDIE model consists of 5 components that are interrelated and structured systematically, meaning that from the first to the fifth stages in its application it must be systematic, not random. The five stages include; analysis, design, development, implementation and evaluation [7]. Because it is simple and systematically structured, this design model is easy to understand and apply. However, in this study not all stages were carried out, the research was limited to the stages of textbook development based on the analysis of historical thinking. The essence of this research is how to formulate complex historical learning materials based on historical thinking, including chronological thinking, causality, interpretation, three-dimensional thinking, and the ability to explore the meaning and values of historical events. So as to produce a history textbook suitable for use in the field. The focus of this research is the History of Islamic Civilization in Indonesia.

\section{RESEARCH RESULTS AND DISCUSSION}

In essence, history learning has three main objectives, namely academic skills, historical awareness, and nationalism. Academic skills to practice thinking skills, in historical treasures are called historical thinking. Historical thinking is a systematic step that must be taken to solve problems in order to produce historical products [9]. Seixas and Peck stated "historical thinking: historical cognition as specified by as the process by which students employ procedural knowledge and disciplined inquiry" [3]. Wineburg also reveals, 'historical thinking demands that we reconcile two opposing views; first, the way of thinking we use today is an indelible legacy, and second, if we don't try to get rid of that legacy, we inevitably have to use "presentism", that is, looking at the past from the perspective of the present [2]. In essence, Wineburg firmly states that there is a continuity of the past that shapes the present, as well as changes in elements, values and social order as a form of reinterpretation of changing times.

It is undeniable that many historians have discussed Historical Thinking, from Sam Wineburg to Mestika Zed. From the historical thinking, it can be concluded that several components that build historical thinking, among others; Think chronologically; Thinking about causality; Interpretation; Think of the three dimensions of time; and the skill of taking the moral dimension of any historical event. All of these components are related to one another.

Historical learning material is formulated based on an analysis of historical thinking and is presented in the textbook of the History of Islamic Civilization in Indonesia. Quite a lot of research on historical thinking and its application in history learning, such as the writings of Martin Merkt, etc. entitled "Learning With Videos vs Learning With Print: The Role Of Interactive Features". This article discusses the use of video media in the learning process by comparing the patterns of using textbooks with the use of videos in the context of the same content [10]. However, Merkt's research only focuses on the comparison between the use of videos and the use of textbooks in the learning process in the classroom. However, the effect was not analyzed on the achievement of learning objectives, nor did the form of video and type of video be discussed.

Then the writing of Basri, et al., which is published in the Journal of Chronology which discusses "How Should History Be Taught?". This paper discusses the characteristics of history and what models are most suitable for learning history in the classroom, so that he concludes that historical thinking can be integrated into a model of historical learning. The stages of historical thinking are adjusted to the syntax of the model, so that an appropriate historical thinking model is born to be applied in history learning. The syntactic stages adopted from historical thinking include chronology, causality, interpretation, three dimensions of time and value or interpretation of historical events that have been studied together [4].

The discussion of historical thinking is very much about its application in historical learning media, such as the writing of Rosida et al., which discusses comic strip media which contains historical learning material based on 
historical thinking. The presentation of material about the entry of Islam to Indonesia in comics is plotted based on the division of historical thinking known as 'The Five C's' formulated by Zed [11], namely, $\mathrm{C} 1=$ Time of replacement; $\mathrm{C} 2=$ Causality; $\mathrm{C} 3=$ Context $; \mathrm{C} 4=$ Complexity ; $\mathrm{C} 5=$ Contingency. The picture and narrative of the comic strip containing 'The Five C's' is made on a separate page because it emphasizes the aspects that build historical thinking. The results showed that the application of historical thinking in comics is suitable for use as a medium for learning history [12].

Not only media, historical thinking is also applied in writing papers or essays which are one of the main tasks of students in learning history, as written by Oktariano, et al., writing about the application of historical thinking in essay writing. . The research that gave birth to this essay writing guidebook aims to train students' ability in writing essays, but also to train students in analyzing historical thinking. The essay descriptions written based on historical thinking analysis are designed in a structured manner according to the stages of the thinking process, so that this essay manual is suitable for use [13].
In this study, historical thinking becomes a guide in studying the material on the History of Islamic Civilization in Indonesia. Each review of material contains a component of Historical Thinking, which consists of chronological thinking, causality thinking, interpretation, threedimensional thinking, and the value or meaning contained in the event. For chronology and causality, it is written directly in the table before the description of the change in events, while interpretation, three dimensions of time, and value are presented through questions inserted in each sheet. This is done with the consideration that chronology and causality serve to construct historical narratives or events, but interpretations, the three dimensions of time, and values, are influenced by the reader's basic knowledge. So, it becomes commonplace if a person's interpretation of the same event can be different, depending on the way of thinking and the point of view used.

The following is an example of a description of the material that has been formulated based on Historical Thinking analysis.

Table 1. Example of a description of the material

\begin{tabular}{|c|c|}
\hline \multicolumn{2}{|r|}{ THE KINGDOM OF SAMUDERA PASAI } \\
\hline Chronological & $\begin{array}{l}\text { In the range of 1220-1275 AD, precisely in the 13th century AD, the first Islamic empire named } \\
\text { Samudera Pasai was founded. Located approximately } 15 \mathrm{~km} \text { east of Lhokseumawe, Nangro Aceh, the } \\
\text { kingdom of Samudera Pasai was led by the first king named Sultan Malik as-Saleh or formerly known } \\
\text { as Marah Silu [14]. } \\
\text { Long before this kingdom appeared, since the } 7 \text { th and } 8 \text { th centuries AD Muslim traders from the } \\
\text { Arabian peninsula, Persia (Iran), and other Middle Eastern countries had started to play an important } \\
\text { role, and took part in international trade and shipping networks. a lot more. far. far from the Gulf of } \\
\text { Aden, Persi Bay through the Indian Ocean - the Strait of Malacca to the Chinese Ocean [15]. } \\
\text { In } 1292 \text { AD, the sultan Malikul Saleh received a visit from Marco Polo, an explorer from Venicia, Italy } \\
\text { who was currently leading a group that brought the queen from China to Persia. On their way, } \\
\text { Marcopolo and his } 2,000 \text { followers stopped by at the same time staying in Samudera Pasai for about } \\
\text { five months. } \\
\text { During his tenure, Sultan Malikul Saleh married Perlak's daughter, Gangga Sari. At that time the Perlak } \\
\text { Kingdom was experiencing many setbacks along with the growth and development of Samudera Pasai. } \\
\text { Both were awarded two children, namely Mohammad Malik Al-Zahir and Abdullah Silu [14]. } \\
\text { During the reign of Sultan Malik As-Saleh, the Kingdom of Samudera Pasai had a major contribution } \\
\text { to the development and spread of Islam in Indonesia and Southeast Asia. One proof of its contribution } \\
\text { is marked by the kingdom of Samudera Pasai which sent many scholars and preachers to spread Islam } \\
\text { to the island of Java. In addition, there are also many scholars who study religion in Samudera Pasai. } \\
\text { One of them, Syekh Yusuf, a Sufi and scholar who spread Islam in South Africa, came from Makassar } \\
\text { [15]. }\end{array}$ \\
\hline Causality & $\begin{array}{l}\text { 1) The growth of this Kingdom cannot be separated from its geographical location which has always } \\
\text { been touched by international shipping and trade through the Strait of Malacca which has existed } \\
\text { since the first century AD. }\end{array}$ \\
\hline
\end{tabular}




\begin{tabular}{|l|l|}
\hline 2) The development of shipping and trading networks through the Strait of Malacca since these \\
centuries was also caused by efforts to develop power in West Asia under Umayyah (660-749), in \\
East Asia under the T'ang Dynasty (618-907). ), and Southeast Asia under Sriwijaya (7-14 \\
centuries AD). \\
3) Sultan Malikul Saleh was ordained by Sheikh Ismail as a sultan in the Sultanate of Samudera Pasai \\
based on several considerations. First, the Mamaluk dynasty needed strong indigenous and Muslim \\
communities who adhered to the Shafi'i school of thought. Second, based on Sheikh Ismail's \\
opinion, Merah Silu would be able to eradicate the Shiite sect that was still rampant on the east \\
coast of Sumatra. Third, the Mamaluk Dynasty hoped that Silu Merah could take over the pepper \\
trade experts from the hands of Persian, Arab and Gujarati traders who were Shia Muslims. During \\
the reign of Sultan Malikul Saleh, many Shi'ites who crossed over to become Muslims with the \\
Shafi'i sect for reasons of gain and loss.
\end{tabular}

The presentation of chronological material and causality is deliberately plotted in the table as an introduction to the description in the discussion. The material is arranged according to the chronological structure of the discussion, such as the beginning or birth, the process of development, the peak of its glory, to its collapse and destruction. Every chronological structure contains causality, interpretation, three dimensions of time, and value. Interpretation is mostly conveyed through questions, because in fact interpretation is an opinion based on historical facts read by students, interpretation is very much influenced by basic and cognitive knowledge about a matter or event, so that each child can have a different interpretation. against the same event. For example in the Sultanate of Samudera Pasai, Meurah Silu or the government of Malikul Saleh, many Shia people changed their direction to become Muslims with the sect of Shafi'i. Children's interpretations may differ regarding the incident, they may change their flow because of the order of the Sultan or the King, and it could also be because of their security problems in trading, or because their aqidah has been straightened out by the ulama appointed by the sultan.

Then a discussion about thinking three dimensions of time. From the event of the appointment of Meurah Silu, who was the son of the area of origin as the Sultan, ruled in the Samudera Pasai Sultanate. Meanwhile, the pioneer and initiator was Sheikh Ismail from Mecca. Currently this event is still ongoing, where the leader of a region is a son of the region himself, even though he was born and raised in another area, as long as his parents or one of them comes from that area he can. run for leadership in that area in the election. In the future, this will still apply, considering that there are still some who are not regional leaders who are leaders in their regions, their leadership tends to fail or not succeed, because of the many obstacles or pressures from their surroundings. One of the values that can be taken from the event is the strategy and skills in reading situations that affect the sustainability of one's leadership.

\section{CONCLUSIONS}

Historical thinking is an absolute skill for both educators and students. Without this ability, history learning is only a description of dry facts that are of no use to this life, not only the life of individuals, but also the life of the nation in the future. Historical thinking is not only limited to approaches, models, media, methods, etc, in history learning. The ability to think historically can also be applied in the preparation of textbooks, which so far have not been or have not been worked on. The importance of learning resources in the form of textbooks that make historical thinking as the basis for discussing historical material not only hones children's analytical skills but also helps teachers to stay on track when doing classroom learning, making discussions more quality and rich in analysis, so as to be able to open students' insights in facing the phenomenon of national life today.

\section{ACKNOWLEDGMENTS}

LP2M UNP which has funded research, reviewers, and students majoring in history class 2017, 2018, 2019, which became research respondents.

\section{REFERENCES}

[1] Banks, James A. 2004. Teaching for Social Justice, Diversity and Citizenship in a global world. The Educational Forum, vol. 68, 286 - 298.

[2] Wineburg, Sam. 2010. Berpikir Historis. Jakarta: Yayasan Obor.

[3] Seixas, P. \& Peck, C. 2004. "Teaching Historical Thinking." Dalam A. Sears \& I. Wright (Eds.), Challenges and Prospects for Canadian Social 
Studies (pp. 109-117). Vancouver: Pacific Educational Press.

[4] Basri, Iqrima \& Hastuti, Hera. 2020. "Bagaimana Sejarah Seharusnya Diajarkan?.” Jurnal Kronologi, vol 2, no. 4, hal. $140-148$.

[5] Johanson, Lisbeth Bergum. 2015. The Norwegian Curriculum In History And Historical Thinking: a Case Study Of Three Lower Secondary Schools. Acta Didactica Norge (Vol. 9, No 1 tahun 2015)

[6] Abdullah, Hedya Sasha Binti, dkk. 2019. Implementation of Historical Thinking Skill Among Malaysian Students using History Textbook: Concept, Issues and Challenges. Social Sciences, Education and Humanities (GCSSSEH). Volume 2, Tahun 2019.

[7] Sugiyono. 2015. Metodologi Penelitian Pendidikan. Bandung: Alfabeta.

[8] Warsita, B. 2008. Teknologi Pembelajaran. Jakarta: PT. Rineka Cipta. [14] Abdullah, Taufik. 2012. Indonesia dalam Arus Sejarah (Jilid 3). Jakarta : Ichtiar Baru Van Hoeve
[9] Foster, S.J. \& Padgett, C.S. 1999. Authentic Historical Inquiry In The Social Studies Classroom. The Clearing House, 72, 357.

[10] Merkt, Martin., etc. 2011. Learning With Videos vs Learning With Print : The Role Of Interactive Features. Elsevier vol. 21 tahun 2011, hal. 687-704.

[11] Zed, Mestika. 2018. Tentang Konsep Berpikir Historis. Lensa Budaya: Jurnal Ilmiah Ilmu-Ilmu Budaya, vol. 13, no.1.

[12] Rosida, Aulia Tiara \& Hastuti, Hera. 2020. "Inovasi Komik Strip Berlandaskan Analisis Historical Thinking sebagai Media Pembelajaran Sejarah SMA.” Jurnal Kronologi, vol 2, no. 4, hal. 224-234.

[13] Oktariano, Febry \& Hastuti, Hera. 2020. "Buku Panduan penulisan Esai Berdasarkan Analisis Historical Thinking. "Jurnal Kronologi, vol 2, no. 4, hal. $188-198$.

[14] Abdullah, Taufik. 2012. Indonesia dalam Arus Sejarah (Jilid 3). Jakarta : Ichtiar Baru Van Hoeve

[15] Ricklefs, M.C. 2008. Sejarah Indonesia Modern 12002008. Jakarta: PT. Serambi Ilmu Semesta 